\title{
A Contrastive Study of Chinese and English Idiom
}

\author{
Xinzhuo Jiang ${ }^{1, a}$ and Jiang Liü, L, $^{*}$ \\ ${ }^{1}$ School of Foreign Languages, Yulin University, China, 719000 \\ ${ }^{2}$ School of Management, Yulin University, China, 719000 \\ a250883726@qq.com, b52186531@qq.com \\ * The Corresponding Author
}

Keywords: Idioms; Contrast; Intercultural communication

\begin{abstract}
Idioms, which reflect the longstanding and profound culture of the East and the West, are regarded as the fruit of human wisdom. This thesis makes a contrastive study of Chinese and English idioms, which is based on the Contrastive Linguistics Theory and analyzes idioms from Intercultural Communication between Chinese and the western. Through the contrastive study of Chinese and English idioms, people will understand the differences between Chinese and Western cultures better.
\end{abstract}

\section{Introduction}

Idioms, one of the most important fruit of human language culture, which reflect the experiences of people's life. Idioms make our daily communication more vivid by providing objective information and personal feelings.

Both Chinese and English have a long and rich history, produce a lot of popular idioms. Some of them have the same meanings, meanwhile, some of them have the different meanings. Idioms are the heritage of history, presenting the differences in the cultural phenomenon, the national characteristics, history, geography, customs, religion and so on. Idioms carry different national cultural characteristics and cultural information, most of the idioms are not the same, so it is necessary to make a contrastive study of idioms.

\section{The Classification of Chinese and English Idioms}

The Classification of Chinese Idioms. Chinese set phrases is an important part in Chinese. According to The Modern Chinese Dictionary, "set phrases" is defined as "well-established, concise, fixed phrases or short sentences consisting of four characters" (2000:315). Examples are as follows:

因人而异: depend on the individual

刮目相看: look at sb. with new eyes

From the examples above, we can find that most of the Chinese set phrases are made up of four characters. The definition of Chinese sayings is given in Modern Chinese Dictionary: "widespread, popular and stereotyped phrases, which are terse and figurative, and mostly created by the working people to reflect their wishes and life experience"(1983:862). This definition is widely used by ordinary people.

Chinese sayings are informal and widely used in oral language, which are popular and easy to understand. Here are some examples: 活到老学到老(It's never too late to learn), 跑得了和尚跑不 了庙(The monk may run away, but the temple can't run with him), 知人知面不知心(It's easy to know men's faces, but not their hearts).

The Classification of English Idioms. Set phrases are the core part in English. Set phrases refer to the collocation and composition of the words, which are relatively tight, and also refer to conventional expressions with a specific meaning. So the meaning of each part can not be regarded as the meaning of the whole unit. Here are some examples, "catch one's eyes", "as poor as a church mouse", "bark up the wrong tree", "flesh and blood".

The definition of colloquialism in Longman Dictionary of Contemporary English(1998:280) is 
"an expression used in, or suitable for, ordinary, informal, or familiar conversation"(2004:317). In Oxford Advanced Learner's Dictionary, the colloquialism is: "a word or phrase that is used in conversation but not in formal speech or writing"(1997:326). Colloquialism is used in conversation and informal occasion. The colloquialism is also the crystallization of common people. Here are some examples,

It's a piece of cake!

It means something is very easy to do.

Wear your heart on your sleeve.

To freely show and express all of your emotions, as though your heart were on the outside of your body.

\section{A Contrastive Study of Chinese and English Idioms in Sources}

Similarities in the Sources of Chinese and English Idioms. Most idioms come from the ordinary people's daily life. The working people have created many idioms in their work and life. "Sailors", for example, invented a lot of vivid phrases, which related to the ocean. These idioms are not only concise, verbal and vivid, but also closely related to life, so idioms were widely used in people's everyday life. As a result, Chinese and English have corresponding idioms in some ways, but with different numbers and different views.

From Reading and Learning. A large number of idioms in Chinese and English are related to reading and learning. In contrast, native English speakers pay more attention to the increase of learning and knowledge. For example, by the book(按常规), read between the lines(了解言外之意), get into somebody's black book(招致某人的不满). In China, the older times, if someone wants to be successful, the only way is to learn well. Hence, there are many idioms in this aspect, such as 名 列前茅(Be among the best of the successful candidates), 金榜题名(One's name is put on the published list of successful candidates), 学而则优仕(A good scholar can become an official).

From Literary Works. In many well-known literary works, some words, phrases, sentences have been selected and have a specific meaning, which are used independently. Such as (1) have one's pound of flesh (from Shakespeare's play "The Merchant of Venice"); (2) out of joint (from Shakespeare's play "Hamlet"); (3) wear one's heart upon one's sleeve(from Shakespeare's play "Othello"). Similar to English idioms, in China, there are also many idioms, which are originated from literary works. They are handed down from generation to generation, and becoming classic. Here are some examples:

山穷水尽疑无路,柳暗花明又一村一一陆游《游山西村》(Where hills bend, streams wind and the pathway seems to end, past dark willows and flowers in bloom lies another village.)

过而能改, 善莫大焉—《左传.宣公二年》(It is the best thing that if a person makes a mistake, he can then correct it.)

Dissimilarities in the Sources of Chinese and English Idioms. Although most of the Chinese and English idioms have many similarities, they spring from completely different social and geographical environment. So, there are still many differences existed in Chinese and English idioms.

From Entertainment and Activities. Entertainment and activities reflect the daily life of the British and Chinese. Both English and Chinese have a large number of idioms, but there are many different ways of entertainment in these two countries.

In the past, Chinese focused on improving personal skills, such as playing musical instruments, playing chess, and painting, which they believe that these ways are important signs of reflecting one's ability. Hence a great many relevant idioms formed, for example, 乱弹琴(talk nonsense), 琴 棋书画(lute-playing, chess, calligraphy and painting-accomplishments of a scholar of the old school). Other examples of Chinese idioms about entertainment and activities are as follows: 玩物 丧志(Riding a hobby saps one's will to make progress), 玩火自焚(Whoever plays with fire willperish by fire), 当局者迷,旁观者清(The spectators see the game better than the players). 
In Britain, there are many idioms associated with playing cards. For example, "speak by the card”(说话有把握), “follow suit”(效仿), “pull one's cards on the table”(公布自己的计划或打算). In addition to playing cards, such as sports competitions, also have impact on English idioms, such as “straight from the horse's mouth”(从可靠方面直接得来的消息), “down and out”(倒下出局;击 败), “play the game”(光明正大), “play into somebody’s hands”(因失算而使某人占上风).

From Religion and Belief. Religion is a kind of cultural phenomenon. Idioms are closely related to culture, so they can reflect the influences of religious. Hence, lots of idioms are related to God. For example, “God bless you!”(上帝保佑你), “God helps those who help themselves.”(天助自助 者), “go to the church”(去教堂做礼拜). There are many idioms coming from “The Bible”. Here are some examples, “one's cup runs over”(幸福极了), “bone of the bone and flesh of the flesh” (骨中 之骨,肉中之肉), “as old as Adam”(很古老的,陈旧的) and so on.

In contrast, China is a multi-religious country, and Buddhism has great influence on Chinese culture. A large number of words and idioms derived from Buddhism, for example, 功德无量 (boundless beneficence), 借花献佛(present Buddha with borrowed flowers-make a gift of something given by another), 临时抱佛脚(embrace Buddha's feet in one's hour of need—seek help at the last moment).

\section{Implications on Cross-cultural Communication}

Differences in Social Custom. Social and historical factors influence the culture, so, different nations are also have different culture. With a long history, idioms are embodied in many aspects of human life. As a result, a large number of idioms are related to their own customs. Without the existence of language and idioms, people can not form the activities of daily life.

The paper will use the attitude of the East and the West to the cat as an example. Chinese people love cats very much, use "cat" to describe people greedy, so there is an idiom, "look like the cat that swallowed the canary”(偷了腥的猫); In the west, a cat is used to describe a malicious woman, for example, “cats hide their claws"(知人知面不知心); Sometimes people think that cats are not so honest, so in English, there are "honest as a cat when the cream is out of reach". Chinese people often curse the cat, which is the representative of hypocrisy. Nevertheless, cat is a tough animal, so there is “a cat has nine lives” and a Chinese idiom completely corresponded: “猫有九条命”.

Besides, food is one of the aspects of cultural tradition that are reflected in English idioms. Bread and butter are usual kind of food in daily meals. "to earn one's bread" means "to make a living", "to butter both sides of the bread" is used to mean "to obtain a comfortable living". In China, most of the areas especially the south grow rice, so many idioms have to do with rice: 巧妇难为无米之炊 (Even the cleverest housewife can't cook a meal without rice), 不当家不知柴米贵(He who takes charge knows the responsibility)

The above shows that in Britain and China, one's attitude to cat and food are of great differences, which indicate different social customs reflected in Chinese and English idioms.

Differences in Cultural Implication. Due to the differences in life styles and social customs, a specific thing may have different idioms and different meanings in Chinese and English cultures. Here are some examples:

When people talk about the animals, the first thought is the dog, because dogs are the most familiar and most intimate animals. There are many idioms about dogs. But the real implied meaning of them in Chinese and English cultures are quite different. British love dogs, they think dogs are their close friends and family members. Such as “clever dog”(聪明伶俐的人), “big dog”(大人物), “lucky dog”(幸运的人) and so forth. Although there are derogatory idioms like “dirty dog”(坏蛋), this is not the mainstream.

On the contrary, Chinese treat the dogs are entirely different from British. Dogs are the best friends of human beings, and they always being faithful to their masters. But most of idioms about dogs are derogatory, for instance, 丧家之犬(a homeless dog), 打落水狗(beat a drowning 
dog-completely crush a defeated enemy). Other idioms which are often used are as follows:

狗嘴里吐不出象牙(No ivory issues from the mouth of a dog.)

狗急跳墙(A cornered beast will do something desperate.)

Although the British and Chinese people have the habits of raising dogs, they have different views on dogs. Traditionally, Chinese people look down upon dogs and often use them to describe people and things that are bad. While most British think that dogs are reliable friends and often use dogs to compare people's behavior.

\section{Conclusion}

As the essence of language, idioms are vivid, concise and full of wisdom. There are all kinds of idioms, which add more colors to languages. Sources of idioms are various. A contrast of the sources of English and Chinese idioms shows that there exist similarities as well as dissimilarities. Idioms reflect culture from various aspects. To understand idioms, some knowledge of culture is indispensable.

Despite the writer has put great efforts to this paper, there are still some limitations exist in this thesis. For example: the study on Contrastive Linguistics is not deep, fewer classic idiomatic examples are listed in the thesis. So, the writer would do further research from some new perspectives.

\section{References}

[1] Hornby, A.S. Oxford Advanced Learner's English-Chinese Dictionary(The Commercial Press, Beijing 1997)

[2] Y.P. Li: English Idiom and Their Cultural Origin(Nankai University Press, Tianjin 2004)

[3] S.P. Luo: A Study on English Idioms(Shanghai Foreign Language Education Press, Shanghai 2006)

[4] Neufeldt, V. Webster's New World Dictionary(Prentice Hall General Reference, New York 1993)

[5] Procter, P. Longman Dictionary of Contemporary English(Longman Group Limited, London 1978)

[6] Richard, A. American Slang Dictionary(2ed)( McGraw-Hill, Network 2007)

[7] Smith, L.P. Words and Idioms(Constable and Company Ltd, London 1925)

[8] Watson,O. Longman Modern English Dictionary(Richard Clay the Chaucer Press, London1976) 